\title{
Long-term biological fate of polyurethane aortic prostheses
}

\author{
VOINEA MARINESCU, EXACUSTODIAN PÁSŞESCU, \\ and STEL, A C̆̈RNARU \\ Departments of Cardiovascular Surgery and Experimental Pathology, Fundeni Clinical Hospital, \\ Bucharest, Romania
}

A study was carried out to investigate the biological fate of spongy polyurethane aortic prostheses after a period of implantation of 7 to 10 years in dogs. The present findings indicate that this material is in a sense accepted by the organism (not only tolerated) because almost complete reorganization of the arterial elastic structures inside the prostheses and the formation of arterial branches from the prostheses were observed.

The list of synthetic materials suggested for vascular replacement is impressive. Experience has reduced them to two or three plastic materials. Past experience has shown that imaterials other than autologous tissue must be carefully tested before such materials can be recommended for widespread clinical use. Investigations of other authors (Dreyer, Akutsu, and Kolff, 1960 ; Wesolowski, 1963, 1965 ; Wesolowski, Fries, Domingo, Liebig, and Sawyer, 1963 ; Fry, DeWeese, Kraft, and Ernst, 1964) concerning the importance of the biological porosity of the vascular prosthesis in its longterm performance have prompted us to study spongy polyurethane as material for aortic prosthetic grafts. Most of these authors (Wesolowski, 1963, 1965 ; Wesolowski et al., 1963 ; Fry et al., 1964) believe that porosity rather than the type of synthetic material is a prime factor in determining the biological fate of the prosthetic graft.

This paper describes the biological changes in the aortic prosthetic grafts of spongy poly- urethane after a period of implantation of 7 teb 10 years.

\section{MATERIAL AND METHOD}

Since 1960 , the possibility of replacing the aortio wall with a spongy polyurethane prosthesis has beem investigated in our laboratories. Fifty-two dogs wit thoracic or abdominal aortic replacement by spong polyurethane prostheses have been used in our studies Adequate tubes made of polyurethane VC sponge (5740X1, B. F. Goodrich Chemical Company, Avo Lake, Ohio) according to the technique of Dreyer et al. (1960) have been used as aortic prostheses Short-term functional and microscopical changes if these prostheses have already been reported (Marink

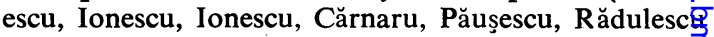
and Racotă, 1964).

Nine of the 13 dogs with thoracic or abdomina aortic prostheses, kept since 1960 for long-term ob servation, were used in the present study. Details of the aortic prostheses in these dogs are given in Tabe I. Aortography was performed in all dogs befor sacrifice to investigate the patency of the prostheses? Necropsy was performed on each dog and the aortif

T A B LE I

DETAILS OF SPONGY POLYURETHANE TUBES USED FOR THORACIC OR ABDOMINAL AORTIC REPLACEMENT IN NINI DETAILS OF SPONGY POLYURETHANE TONG-TERM EXPERIMENTS IN DOGS

\begin{tabular}{|c|c|c|c|c|c|c|}
\hline Dog No. & $\begin{array}{c}\text { Aortic } \\
\text { Replacement }\end{array}$ & $\begin{array}{c}\text { Length of } \\
\text { Prosthesis (mm) }\end{array}$ & $\begin{array}{c}\text { Inner Diameter } \\
\text { of Prosthesis }(\mathrm{mm})\end{array}$ & $\begin{array}{l}\text { No. of Layers } \\
\text { of Polyurethane }\end{array}$ & $\begin{array}{l}\text { Time of Implan- } \\
\text { tation }(\mathrm{yr}, \mathrm{mth})\end{array}$ & Cause of Death \\
\hline $\begin{array}{l}\text { AP-1 } \\
\text { AP-25 } \\
\text { AP-26 } \\
\text { AP-41 } \\
\text { AP-42 } \\
\text { AP-53 } \\
\text { AP-57 } \\
\text { AP-63 } \\
\text { AP-68 }\end{array}$ & $\begin{array}{l}\text { Abdominal } \\
\text { Thoracic } \\
\text { Thoracic } \\
\text { Thoracic } \\
\text { Abdominal } \\
\text { Abdominal } \\
\text { Abdominal } \\
\text { Thoracic } \\
\text { Thoracic }\end{array}$ & $\begin{array}{l}40 \\
70 \\
50 \\
60 \\
40 \\
50 \\
40 \\
60 \\
60\end{array}$ & $\begin{array}{l}8 \\
11 \\
11 \\
12 \\
8 \\
7 \cdot 8 \\
7 \cdot 8 \\
8 \\
6 \cdot 8\end{array}$ & $\begin{array}{l}2 \\
3 \\
3 \\
3 \\
2 \\
2 \\
2 \\
2 \\
3\end{array}$ & $\begin{array}{r}7,9 \\
8,5 \\
10,0 \\
10,0 \\
10,0 \\
7,6 \\
10,0 \\
9,1 \\
10,0\end{array}$ & $\begin{array}{l}\text { Other than prosthesis } \\
\text { Other than prosthesis } \\
\text { Sacrificed } \\
\text { Sacrificed } \\
\text { Sacrificed } \\
\text { Other than prosthesis } \\
\text { Sacrificed } \\
\text { Other than prosthesis } \\
\text { Sacrificed }\end{array}$ \\
\hline
\end{tabular}



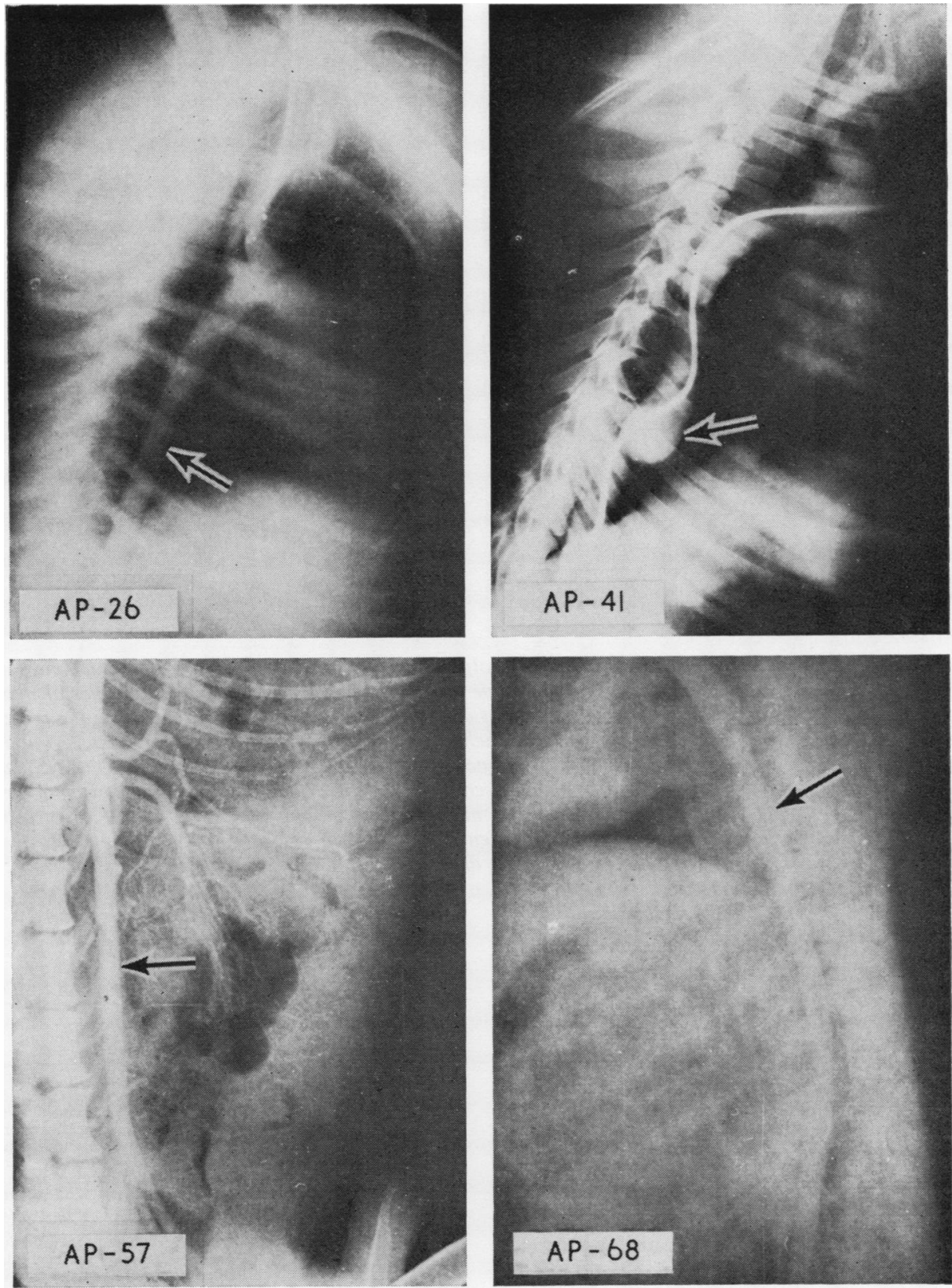

FIG. 1. Aortograms performed in four dogs with aortic prostheses of spongy polyurethane 10 years after implantation. Note regular lumen of prostheses in three of these dogs and arterial branches from the prosthesis in dogs AP-26 and AP-57. Arrows indicate prosthetic aortic replacement. 

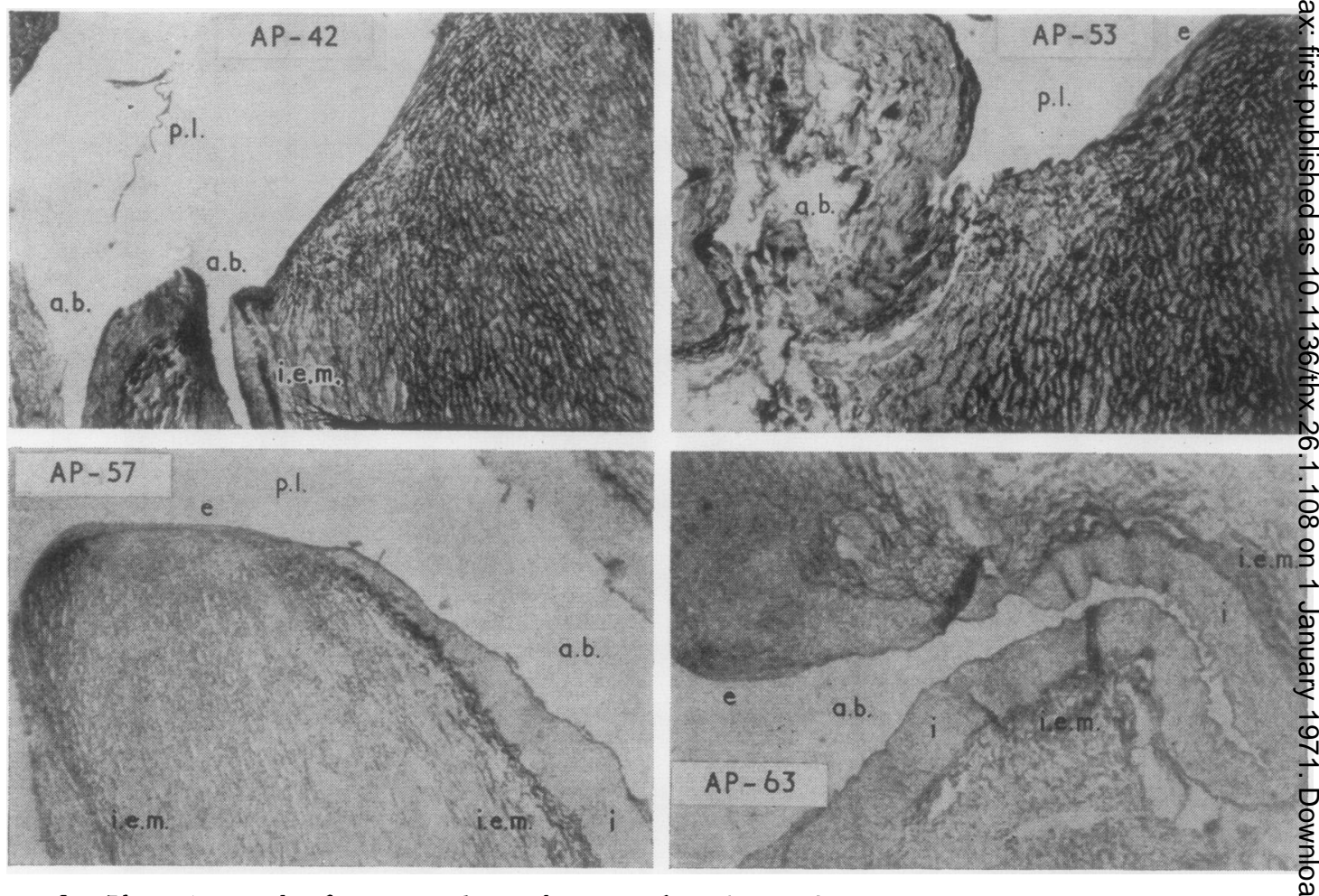

FIG. 2. Photomicrographs of aortic prostheses of spongy polyurethane in four dogs 10 years after implantation (Weige层 stain). AP-42: Note reorganization of elastic structures inside prosthetic wall and two arterial branches of muscular type from the aorta at its level. AP-53: A transverse section of one of these branches in its route inside the prosthetic wal Note on upper right side of photomicrograph normal endothelium covering inner surface of prosthesis. Note also almosg complete disappearance of synthetic material and a non-concentric disposition of elastic lamellae. AP-57 and AP-63. Transverse sections of aortic prostheses with longitudinal sections of two of their arterial branches showing structur details. Note almost complete disappearance of synthetic material, less evident reorganization of elastic structures im the prostheses and inner elastic membranes limiting an evident intima in their arterial branches. Note also normal endo $\bar{g}^{2}$ thelium covering inner surface of prostheses $(\times 21)$. a. b., arterial branch; i. e. m., inner elastic membrane; i. intima e, endothelium; p. 1., prosthetic lumen.

segment with the prosthetic graft was removed for histological examination.

\section{RESULTS}

Radiographic and necropsy examinations of aortic prostheses of polyurethane sponge 7 to 10 years after their implantation revealed each to be patent (Fig. 1; Table II). In three dogs a slight dilatation of the prosthetic graft was observed but no haemodynamic impairment seemed to be produced, because these animals survived from 8 to 10 years without any clinical manifestation of cardiac insufficiency or of ischaemia distal to the prosthetic graft. (These prostheses underwent a limited degree of dilatation, probably because the layers of their walls were not completely coalescent before they were implanted.) Characteristically, there was normal endothelium covering the internal surface of all the prostheses and several of them presented arterial branches of different bores (Table II ; Fig. 2).
T A B L E I I

NECROPSY FINDINGS (SAME DOGS AS IN TABLE I)

\begin{tabular}{|c|c|c|}
\hline $\begin{array}{l}\text { Dog } \\
\text { No. }\end{array}$ & $\begin{array}{l}\text { Aortic } \\
\text { Replacement }\end{array}$ & Necropsy Findings \\
\hline AP-1 & & $\begin{array}{l}\text { Graft open; normal endothelium coveri } \\
\text { internal surface of graft; no dilatation }\end{array}$ \\
\hline AP-25 & Thoracic & $\begin{array}{l}\text { Graft open; normal endothelium coverios } \\
\text { internal surface of graft; slight dilatation }\end{array}$ \\
\hline AP-26 & Thoracic & $\begin{array}{l}\text { Graft open; normal endothelium covering } \\
\text { internal surface of graft; no dilatatiof } \\
\text { small arterial branches from graft }\end{array}$ \\
\hline AP-41 & Thoracic & $\begin{array}{l}\text { Graft open; normal endothelium covering } \\
\text { internal surface of graft; inferior moder } \\
\text { aneurysmal dilatation }\end{array}$ \\
\hline AP-42 & Abdominal & $\begin{array}{l}\text { Graft open; normal endothelium coverfeg } \\
\text { internal surface of graft; slight dilatatiog } \\
\text { evident arterial branches from graft }\end{array}$ \\
\hline AP-53 & Abdominal & $\begin{array}{l}\text { Graft open; normal endothelium covering } \\
\text { internal surface of graft; no dilatationg } \\
\text { evident arterial branches from graft }\end{array}$ \\
\hline AP-57 & Abdominal & $\begin{array}{l}\text { Graft open; normal endothelium coveripg } \\
\text { internal surface of graft; no dilatation; } \\
\text { evident arterial branches from graft }\end{array}$ \\
\hline AP-63 & Thoracic & $\begin{array}{l}\text { Graft open; normal endothelium coveriog } \\
\text { internal surface of graft; no dilatatiof; } \\
\text { evident arterial branch from }\end{array}$ \\
\hline AP-68 & Thoracic & $\begin{array}{l}\text { Graft open; normal endothelium covertig } \\
\text { internal surface of graft; no dilatation; } \\
\text { small arterial branches from graft }\end{array}$ \\
\hline
\end{tabular}


Microscopical examination of the prosthetic grafts showed a striking similarity to normal aortic wall. The fibrous tissue, which initially had grown into the pores of the spongy prosthesis, underwent reorganization resembling the elastic lamellar structure of the normal aorta. This metaplasic process affecting the initial granulation tissue seems to be accompanied by gradual biological digestion of the prosthetic material (Fig. 2). Another histological feature that requires special consideration is the structure of the arterial branches from the prostheses. In three of the five dogs with thoracic aortic prostheses and in three of the four dogs with abdominal aortic prostheses the graft presented arterial branches of muscular type (Table II ; Fig. 2). Their development could be correlated with the length of the prosthesis. It is also conceivable that the tendency to aneurysmal dilatation of the prosthesis might be a circumstance which does not permit re-establishment of arterial branches in this aortic segment (Table II).

\section{DISCUSSION}

Among the factors limiting the clinical use of aortic prosthetic grafts three seem to be important: (1) loss of strength after implantation and subsequent aneurysmal dilatation; (2) thrombic obstruction ; (3) susceptibility to rejection. With regard to spongy polyurethane, Dreyer et al. (1960) established that 'it actually gains strength inside the body, at least up to 6 months after insertion, apparently by the ingrowth of fibrous tissue which binds it into position'. Our previous observations (Marinescu et al., 1964) and the present study confirm this finding and extend its validity up to 10 years after implantation. Moreover, according to our data polyurethane is not only tolerated but, in a sense, accepted by the organism. It permits almost complete reorganization of the arterial elastic structures inside the aortic prosthesis and the formation of arterial branches at its level. It is our opinion that the abnormal healing of spongy polyurethane aortic prostheses and their subsequent early or late failures reported by, us (Marinescu et al., 1964) and others (Dreyer et al., 1960 ; Bernatz, 1965) result from technical errors in preparing the graft rather than from its physical properties or the foreign-body effect of this synthetic thermoplastic elastomer (Marinescu and Păușescu, 1970).

The late reorganization of the entire mass of granulation tissue in this prosthetic material appears to occur in a similar manner to that of any cicatricial tissue in the body, since in most of our present experiments no cicatricial contracture or thickening of the prosthetic wall have been observed. On the other hand, it is interesting to emphasize that our comparative morphological study of the arterial branches from these prostheses and of other regional arteries suggests that the development of such branches is due to the penetration of external arteries into the prosthetic wall. Furthermore, our studies have shown that polyurethane is non-carcinogenic and non-allergenic in the dog.

Our findings, therefore, lead us to believe that polyurethane sponge as a prosthetic material for aortic replacement has been abandoned too early and that, in this respect, it merits further study.

The authors wish to thank Mrs. V. Tomiuc for skilful technical assistance.

\section{REFERENCES}

Bernatz, P. E. (1965). Arterial replacement. Mayo Clin. Proc., 40, 853.

Dreyer, B., Akutsu, T., and Kolff, W. J. (1960). Aortic grafts of polyurethane in dogs. J. appl. Physiol., 15, 18.

Fry, W. J., DeWeese, M. S., Kraft, R. O., and Ernst, C. B. (1964). Importance of porosity in arterial prostheses. Arch. Surg., 88, 836.

Marinescu, V., Ionescu, M., Ionescu, L., Cărnaru, S., Păușescu, E., Rădulescu, A., and Racotă, M. (1964). Proteze vasculare din poliuretan. Probl. Chir. Ortoped. (Buc.), 1, 17.

_- and Păușescu, E. (1970). Organe Artificiale și Grefe de Organe, pp. 69-84. Editura Stiintifică, București.

Wesolowski, S. A. (1963). Materials for repair of vascular defects. Dis. Chest, 43, 290.

(1965). The healing of vascular prostheses. Surgery, 57 319.

- Fries, C. C., Domingo, R. T., Liebig, W. J., and Sawyer, P. N. (1963). The compound prosthetic vascular graft: a pathologic survey. Survey, 53, 19. 